\title{
Den kollaborative kunstens potensial
}

\section{Brit Rian}

Trondheim kommunale kulturskole

NTNU, Norges teknisk-naturvitenskaplige universitet, masterstudent

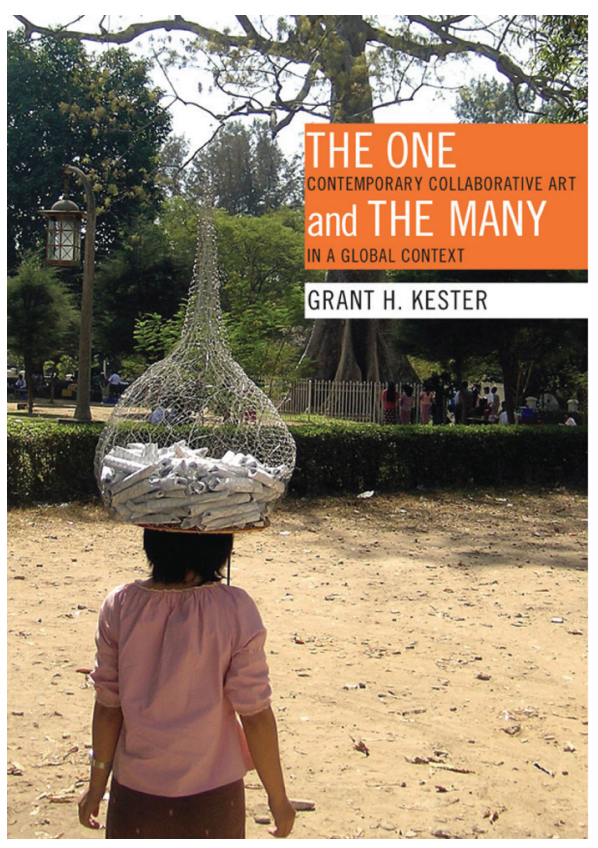

Grant H. Kester, (2011). The One and the Many. Contemporary Collaborative Art in a Global Context. Duke University Press. 320 sider.

I de siste tiårene har mange kunstnere vært tiltrukket av kunstprosjekter som legger opp til samarbeid og deltakelse. Dette fenomenet i kunst er tema for boken The One and the Many - Contemporary Collaborative Art in a Global Context. Ved kollaborativ kunst regnes de deltakendes opplevelser og erfaringer som en del av det kunstneriske arbeidet; i motsetning til mer tradisjonell kunst, der verket er en presentasjon av et objekt eller forestilling presentert for et publikum. Kollaborativ kunst rommer både konseptuelle kunstprosjekter for biennaler og mer aktivistiske prosjekter (Kester, 2011, s. 7-8). Kester omtaler først og fremst kunstfenomenet som "collaborative», men det er en kunstform som også kan kalles relasjonell, deltakende, sosialt engasjert, 
interaktiv og dialogisk og i denne boken bruker han tidvis alle begrepene for å beskrive denne kunsten som mange av dagens kunstnere eksperimenterer med.

Gjennom å bruke estetiske virkemidler har moderne kunst ofte intensjonen om å gi annerledes opplevelser, utfordre konvensjoner og skape ny kunnskap, og kollaborativ kunst har gjerne også disse formålene. Likevel hevder Kester at kollaborativ kunst viser til et paradigmeskifte gjennom å fordre et nytt syn på kunst og kunstteori og hvordan kunstteori og kunstkritikk kan brukes for å legitimere for visse former for kunstproduksjon:

Thus, collaborative practices do not supersede this textual approach. They simply offer a different articulation of a capacity that I take to be central to the constitution of modern art more generally: the ability of aesthetic experience to transform our perception of difference and to open space for forms of knowledge that challenge cognitive, social or political conventions. (Kester, 2011, s. 11)

I denne boka ser Kester nærmere på et utvalg dagsaktuelle og stedspesifikke kunstprosjekter der samarbeidet og deltakelsen blir sett som en del av kunsten. Prosjekter som han ser nærmere på er kunstkollektiver som Park Fiction i Tyskland, Ala Plastica i Argentina og Dialogue i India, og konseptkunstneren Francis Alys When Faith Moves Mountain i Peru. Dette er prosjekter som finner sted på steder som gjerne ikke forbindes med kunst, men i lokalmiljøer og boligstrøk eller steder preget av politisk motstand. Kester skriver om hvordan de forskjellige prosjektene uttrykkes ulikt på de forskjellige stedene og hva disse forskjellene kan si om moderne kunst. Han tar også for seg hva slags kunnskap som kollaborativ kunst skaper (s. 7-9). Med blant annet utgangspunkt i disse kunstprosjektene tar denne boken for seg hvordan kollaborativ kunst berører etiske og estetiske spørsmål og dilemmaer rundt temaer som autonomi, identitet, eierforhold, kunst og samfunn, arbeidskraft, representasjon og beliggenhet.

Boka er inndelt i tre kapitler. I første kapittel Autonomy, Antagonism and the Aesthetic tar Kester opp hvordan estetisk autonomi har blitt så sentralt i moderne kunst og kunstteori (s. 14). Han gir et kort historisk tilbakeblikk over kunstepoker som er viktige for kollaborativ kunst, som avant-garde og neo avantgarde, og han peker på likhetstrekk med dagens kollaborative kunst, som synet på autonomi og motivasjon basert på sosialt engasjement (s. 22). Kester ser nærmere på hvordan kunstprosjekter kan forhandle med kunstnerisk autonomi der sosiale praksiser erstatter det tekstuelle (s. 37). I andre kapittel The Genius of the Place analyserer Kester de stedspesifikke forhold, hvilken status arbeidskraft og individualitet har i kunstverdenen og hva slags kunnskap som de relasjonelle erfaringene kan tilby (s. 15). Kester tar opp utfordringer $\mathrm{i}$ forbindelse med autonom og anerkjent deltakelse, som kunstnere som vanligvis jobber tekstuelt kan møte når de forsøker å praktisere kollektivt. Kunstnerisk identitet er et sentralt tema i dette kapitlet, og i følge Kester berører kollektive kunstprosjekter forskjeller mellom individuell og kollektiv identitet og subjektivitet, som ikke nødvendigvis er enten det ene eller det andre, men heller i bevegelse (s. 74-76). Det tredje kapitel Eminent Domain: Art and Urban Domain tar opp byutvikling og kunst, 


\section{B. Rian}

representasjon av fattigdom og kunst i offentlig rom. Kunstnerisk aktivisme mot byutvikling der økonomiske og politiske interesser dominerer blir diskutert gjennom prosjektet Park Fiction, der kunstnerne mobiliserte deltakelse av flere hundre beboere i en bydel av husokkupanter i Hamburg. Som en alternativ og leken motstand til myndighetens forsøk på å ta over bydelen, ble det skapt mange kreative og deltakende prosjekter (s. 205).

I boka gir Kester uttrykk for både anerkjennelse og tiltro til den kollaborative kunsten og fenomenets potensiale til å bidra til kunnskap og bevisstgjøring i forbindelse til temaer som autonomi, identitet og kunst og samfunn. Han er likevel kritisk til hvorvidt noen av de sosialt engasjerte kunstnerne mestrer å oppfylle sine idealistiske intensjoner. Her stiller Kester seg for eksempel kritisk til representasjonen av fattige, når han ser nærmere på hvordan det er blitt gjennomført både i tidligere og dagsak-tuell kunst. I følge Kesters analyse kan representasjonen ikke bare vise til en objektivisering av de fattige, men også et gammelt syn på publikum som er ubevisste over sine privilegier og derfor må sjokkeres til samvittighet og handlekraft (s. 169-170). Kester hevder at det er et viktig skille mellom arbeid der deltakerne ikke bare representerer planlagt og symbolsk, og prosjekter der deltakelsen er mer autentisk og improvisert. Han trekker fram betydningen av å stille spørsmål ved hvorvidt de kan forstå kom-pleksiteten av samspillet mellom det estetiske og etiske i samarbeidende og deltakende kunst (s. 76).

For many of the artist here, this process begins with the experimental knowledge generated through collective and collaborative practice and an increased sensitivity to the complex registers of repression and resistance, agency and instrumentalization, which structure any given site or context. (Kester, 2011, s. 212)

For de som er interessert i en dypere forståelse av kollaborativ kunst er The One and the Many - Contemporary Collaborative Art in a Global Context en opplysende bok for å få innsikt i dette kunstfenomenet. Gjennom sin analyse av de utvalgte prosjektene og gjennom å se kunstformen i historisk og samfunnsmessig sammenheng gir Kester innsikt og forståelse av hva kollaborativ kunst kan by på av innsikt og utfordringer, og påpeker hvilke faktorer kunstnere behøver å være bevisste for at kunst kan kalles kollaborativ og sosialt engasjert.

\section{Referanse}

Kester, G. H. (2011). The One and the Many. Contemporary Collaborative Art in a Global Context. San Diego: Duke University Press. 